\title{
Telomerase as a target in diagnosis and treatment of cancer in postmenopausal women
}

\section{Znaczenie telomerazy w diagnostyce i terapii onkologicznej u kobiet po menopauzie}

\author{
Natalia Lipińska, Błażej Rubiś \\ Clinical Chemistry and Molecular Diagnostics, Poznan University of Medical Sciences, Poznan; \\ Head of Department: Prof. Maria Rybczyńska
}

Przegląd Menopauzalny 2013; 6: 478-483

\begin{abstract}
Summary
Telomeres and telomerase are responsible for protection and maintenance of genomic stability of all eukaryotic cells. Several studies showed that one of the most distinguishing features of cancer cells is an increased expression and activity of telomerase, in contrast to somatic cells. This gives an opportunity for use of telomerase as a specific marker of cancer lesions or even as a molecular target. However, there are some questions concerning diagnostic specificity of this marker especially in the context of high proliferation potential of normal cells, such as the uterus and ovaries. The proliferation potential, however, decreases due to the menopause syndrome. Women's age and hormonal changes influence the functioning of many tissues, including alterations in telomerase activity of endometrial and ovarian cancer cells. The different characteristics of telomerase activity and telomere length in cells of postmenopausal women give an opportunity to utilize the telomeres and telomerase for the development of new cancer diagnostic tests and therapeutic methods. This work is aimed to summarize the information about the significance of telomeres and telomerase in the diagnosis and treatment of cancer in postmenopausal women.
\end{abstract}

Key words: telomerase, telomeres, ovarian cancer, endometrium, post-menopausal women.

\section{Streszczenie}

Telomery wraz z telomerazą odpowiadają za ochronę oraz utrzymanie stabilności genomu wszystkich komórek eukariotycznych. Liczne badania na ten temat wykazały, że szczególnymi cechami większości komórek nowotworowych są podwyższona ekspresja i aktywność telomerazy w porównaniu z komórkami somatycznymi. Stwarza to potencjalną możliwość zastosowania telomerazy jako specyficznego markera zmian nowotworowych, ale i celu terapii. W odniesieniu do nowotworów układu rozrodczego kobiet pojawiają się jednak wątpliwości związane z wysokim potencjałem proliferacyjnym prawidłowych komórek budujących takie organy, jak macica czy jajniki; tym samym kwestionowana jest specyficzność wspomnianego markera. Potencjał ten jednak zanika wraz z wejściem kobiety w okres menopauzy. Wiek kobiety i zmiany hormonalne wpływają na funkcjonowanie wielu tkanek, zmienia się m.in. aktywność telomerazy w komórkach endometrium i jajników. Odmienna charakterystyka aktywności telomerazy oraz długość telomerów w komórkach kobiet w okresie pomenopauzalnym daje możliwość wykorzystania tych czynników do opracowywania nowych testów diagnostycznych i metod terapeutycznych. Poniższa praca ma na celu podsumowanie informacji dotyczących znaczenia telomerów i telomerazy w diagnostyce oraz terapii onkologicznej kobiet po menopauzie.

Słowa kluczowe: telomeraza, telomery, rak jajnika, endometrium, kobiety po menopauzie.

\section{Introduction}

Cancers are characterized by uncontrolled and unlimited ability to proliferate and metastasize. Many years of research led to the discovery of a number of tumor markers but only few of them reveal proper tissue specificity and diagnostic sensitivity, allowing their use in diagnosis of cancer. In 1984, when telomerase was discovered, new hopes for its use as a universal 
marker of malignant transformation appeared. Human somatic cells are characterized by a limited ability to proliferate, which is a result, among others, of a low level of telomerase expression and activity in these cells. On the other hand, most cancer cells express telomerase and thus maintain high proliferative potential [1]. Changes that occur in the post-menopausal women are complex and multifactorial but, paradoxically, give an opportunity to develop new diagnostic tests and novel methods of cancer treatment, including therapeutic schemes based on the detection of telomerase activity and telomere length. This seems to be of great interest and importance especially since research studies show that approximately $85-90 \%$ of the 3000 kinds of cancers are characterized by high telomerase activity [2].

\section{Telomeres and telomerase}

Telomeres are constitutive elements of eukaryotic chromosomes. They are located at the 3' ends of DNA strands, composed of guanine-rich repeated sequences: 5'-TTAGGG-3', and stabilized by telomere binding proteins (TBP) as well as shelterin complex $[3,4]$. The primary role of telomeres is to protect and maintain the stability of the genome. Further, the specific telomere structures with D-loop and T-loop at the end of chromosome prevent them from nonhomologous end joining (NHEJ) and degradation by exonucleases [5]. Telomeres shorten by 50-200 nucleotides with each cell division as a result of the inability of DNA polymerase to complete replication of the lagging strand ("end replication problem"). Telomere length in human somatic cells ranges from 3 to $12 \mathrm{~kb}$ [6] and it limits the maximum number of cell divisions (Hayflick limit) to several dozen in vitro [7]. Telomere shortening to a critical length results in the loss of telomere protection, which leads to chromosomes instability, stops cell division and replicative senescence may be initiated [8]. Some cells, however, exhibit unlimited capacity for proliferation through the telomerase complex activity. Human telomerase is a multisubunit ribonucleoprotein that belongs to the reverse transcriptases (RT) family and is responsible for de novo addition of TTAGGG repeats onto chromosome ends. Two essential components are necessary for the functioning of telomerase in vitro: telomerase reverse transcriptase catalytic subunit (TERT) and a functional telomerase RNA (TR, TERC) that serves as a template for telomere extension. In addition, the telomerase complex (in vivo) consists of telomerase-associated proteins such as dyskerin (DKC1), NOP10, NHP2, GAR1. It is also stabilized by the shelterin complex proteins with various functions in enzyme biogenesis, localization, and regulation [4, 9]. Some cell lines have been reported to use a telomerase-independent mechanism to maintain the telomere length, known as alternative lengthening of telomeres (ALT), which involves the use of a DNA template and homologous recombination-mediated mechanism of telomere elongation [10]. Thus, there are at least two mechanisms that provide cancer cells to prevent telomeres shortening and to avoid apoptosis.

\section{Telomerase expression and activity}

Production of an active telomerase complex is possible by two major genes expression: TERT - coding for reverse transcriptase and TERC - coding for RNA template. While TERC is constitutively expressed in all cells, the TERT is not. This gene is considered to be a crucial one for the functioning of the enzyme, since the increased telomerase activity mostly correlates with an increased TERT mRNA [9]. Telomerase activity is closely linked to the proliferative potential of cells. Hence, cells at the blastocyst stage and most of the embryonic cells before the $20^{\text {th }}$ week of fetal development reveal high telomerase activity. After birth, telomerase activity is gradually reduced in most somatic cells, with the exception of intensively dividing and self-renewing cells. Elevated activity of telomerase is observed in bone marrow, skin, endometrium, gastrointestinal tract, testis and stem cells [11]. In the peripheral blood, the highest telomerase expression is observed in thymocytes and circulating activated T cells [12]. Along with shortening of the telomere length in peripheral blood cells, the level of telomerase activity in leukocytes decreases with age, until it becomes undetectable in humans about $40 \mathrm{~s}$ [13]. However, the profile of telomerase activity also depends on changes occurring in the body, particularly in the female body during menopause. A decrease in estrogen and progesterone levels leads to changes in cell proliferative capacity in the reproductive system, and changes in the level of those hormones has been linked to changes in telomerase activity in these cells [14].

\section{Telomerase and cancer}

In postmenopausal women an increasing incidence of certain types of cancer is observed. About the age of 50 , the risk of breast, ovarian, endometrial, lung and colon cancer increases $[15,16]$. Both hormonal fluctuations and age are major risk factors for these cancers [16]. In addition, hormone replacement therapy (HRT) results in longer exposure to estrogens and can predispose to the development of these cancers [17]. Many years of research have revealed that telomerase is specifically activated in most malignant tumors. From the diagnostic perspective it is crucial to identify at which stage of carcinogenesis the activity of the enzyme increases. In some cancers, telomerase expression increases gradually with tumor progression, while in others it is observed even in the in situ stage [18-20]. About $90 \%$ of invasive breast cancers and $75-90 \%$ of ductal carcinomas in situ exhibit 
the TERT expression or telomerase activity [19]. Furthermore, a correlation was observed between the increase in the average telomerase activity and tumor progression in $14 \%$ of benign lesions, and in $92 \%$ and $94 \%$ of ductal and invasive carcinoma, respectively [21]. A similar correlation has been demonstrated for lung cancer. In $62-94 \%$ of non-small cell lung cancer (NSCLC), and in almost $100 \%$ of small cell lung cancer (SCLC), telomerase activity is detected and its level correlates with the histological type, severity and survival [20]. For other cancers, telomerase activity values are more diverse, the percentage of telomerase positive bone cancer is $11-58 \%$, for liposarcoma $26-86 \%$ and $56-90 \%$ for renal carcinoma [19, $22,23]$. Noteworthy, skin and colon are also proliferative tissues that display a reduction in proliferative capacity with an increasing age $[11,15,16]$. The studies revealed that these changes are also reflected in telomerase activity as well as telomere length alterations.

As shown in the vast majority of cases, identification of telomerase activity can distinguish cancer from normal tissue, and in some cases and cancer types, the enzyme activity correlates with the tumor stage (Table I).

\section{Telomerase and telomeres as a diagnostic marker in postmenopausal women}

The most significant change in the woman's body during menopause is hormonal changes that alter the functioning of the whole organism. The concentra-

Table I. Telomerase activity in selected normal and cancer tissues

\begin{tabular}{|c|c|c|c|}
\hline \multirow{2}{*}{ Tissue/Organ } & \multicolumn{2}{|c|}{ Telomerase positive (\%) } & \multirow{2}{*}{ References } \\
\hline & Normal tissue & Cancer tissue & \\
\hline \multirow{3}{*}{ endometrium } & $11-89$ & $95-100$ & [19] \\
\hline & 89 & 100 & [34] \\
\hline & 0 & 100 & [31]e \\
\hline \multirow{3}{*}{ cervix } & $0-19$ & $79-100$ & [19] \\
\hline & 0 & 100 & [31]e \\
\hline & n.d. & 100 & {$[23]$} \\
\hline \multirow{4}{*}{ ovary } & $0-33$ & $74-100$ & {$[19]$} \\
\hline & 30 & 96 & [34] \\
\hline & n.d. & $90-97$ & {$[36]$} \\
\hline & 33 & 91 & [23] \\
\hline \multirow{2}{*}{ breast } & $0-4$ & $73-95$ & [19] \\
\hline & 0 & 88 & [23] \\
\hline \multirow{2}{*}{ lung } & $0-4$ & $62-94$ & [19] \\
\hline & 4 & $78-100$ & [23] \\
\hline \multirow{2}{*}{ bladder } & $0-29$ & $79-100$ & [19] \\
\hline & n.d. & 92 & [23] \\
\hline \multirow{2}{*}{ kidney } & 0 & 83 & [23] \\
\hline & $0-75$ & $56-82$ & [19] \\
\hline
\end{tabular}

n.d. - no data in references tion of progesterone and estrogens (estradiol, estrone, estriol) decreases, and the adrenal cortex takes over the function of their production at low levels. Observation studies have suggested that estrogen activates while progesterone suppresses telomerase activity [24, 25]. Therefore, the differences in leukocyte telomere length between women (longer) and men (shorter) are presumably associated with high levels of estrogen in women [26]. Research studies confirm that $17 \beta$-estradiol is an inducer of telomerase activity via induction of TERT transcription [27]. Lee et al. studied two groups of postmenopausal women - treated with hormone replacement therapy (HRT) and without the HRT. They showed that women taking HRT had a significantly higher average telomere length than those without hormone therapy [28]. Moreover, the study of Lin et al. [29] indicated a relationship between the exposure time to endogenous estrogen before menopause and the increased telomere length in peripheral blood cells of women after menopause. It is suggested that lengthening of telomeres indirectly influences the cardioprotective effects of endogenous estrogens and directly causes a delay of cellular senescence [29]. On the other hand, upregulation of telomerase activity, due to the presence of estrogens, is also observed in cancer cells expressing estrogen receptors, such as breast and endometrial cancer. This mechanism enhances the proliferation and progression of cancer and, consequently, evokes controversy over the concept of the use of hormone replacement therapy in postmenopausal women. Paradoxically, it gives the possibility of using selective estrogen receptor modulators treatment (e.g. raloxifene, tamoxifen) that, through the ER receptors, reduce telomerase activity, thereby affecting the transcriptional and post-translational regulation of TERT [30].

Normal endometrial cells in premenopausal women, in contrast to most somatic cells of the organism, reveal telomerase activity, and their level varies depending on the phase of the cycle. Wlaźlak et al. showed that $85 \%$ of endometrial cells in the proliferative phase and $45 \%$ of cells in the secretory phase show telomerase expression [31]. Atrophic endometrium in postmenopausal women loses the ability to proliferate intensively. Moreover, telomerase expression in atrophic cells is significantly lower than in the cells of a proliferative stage and endometrial cancer cells [32, 33]. It was suggested that it might give an opportunity to use the measurement of the expression of telomerase as a marker for distinguishing malignant and normal endometrial cells in postmenopausal women [33, 34].

The tissues exhibiting constitutive telomerase activity include also the ovaries. Expression of the enzyme is particularly high in young ovaries and decreases with age. Kinugawa et al. suggested that the depletion of follicles activity is directly related to the decrease in the telomerase level, which makes the assessment of functional ovarian age possible by measuring telomerase activity 
[35]. Ageing oocytes, due to low telomerase activity, are unable to prevent damage of chromosomes that leads to fertility decline [35]. Like other cancers, about 90-97\% of ovarian tumors show an up-regulation of telomerase activity. A positive correlation was also observed in cases of lymph node metastasis. Despite the telomerase activity in normal ovarian tissue, telomerase can be still perceived as a potential marker in ovarian cancer since in normal tissue, telomerase activity is derived only from the germ line cells that display lower telomerase activity than observed in cancer cells [36].

The leading technique to assess telomerase activity is telomeric repeat amplification protocol (TRAP assay). It engages the polymerase chain reaction (PCR) method and analysis of products of telomerase action, i.e. elongation of primers mimicking telomeres sequence. The detection system is based on qPCR or ELISA assay and, when compared to standards, enables a quantitative measurement [37]. The TRAP assay detects telomerase activity with high sensitivity, even in a single cell. PCR step of the TRAP assay is a source of potential problems, hence several non-PCR methods are also used. One of the most promising alternative methods is isothermic transcription-mediated amplification (TMA) also combined with detection based on hybridization-protection assay (HPA) and telomeric repeat elongation (TRE) based on biosensor technology [38]. The sensitivity of telomerase activity assays may be increased by a simultaneous assessment of hTERT expression. Thus, a combination of these two assays might be useful in early identification of the tumor as well as its classification [39].

Telomere length is closely related to the proliferative rate and lifespan of cells. Short telomeres could be a byproduct of the cancer cell's high proliferative rate but on the other hand, might trigger early carcinogenic events. Some researchers indicate no association of this parameter with the risk of cancer, while others indicate a correlation of both i.e. shorter and longer telomeres, to the increased risk of cancers in postmenopausal women [40, 41]. Wang et al. showed changes in telomere length (shortening or elongation) in $60 \%$ of ovarian, $73.9 \%$ of endometrial, and $64.3 \%$ of cervical cancers [42]. On the contrary, the lack of any clinical significance to telomere length in breast as well as ovarian and endometrial cancers was suggested in some reports [43, 44]. These differences are probably caused by various methods applied and different characteristics of patient groups [41]. Thus, some doubts concerning a direct relation between relative telomere length, mostly measured in peripheral blood cells, and telomere length in cancer cells [45] still remain. However, telomerase activity and TERT expression measurements, complemented by analysis of telomere length and other molecular markers of cancer, have a chance to evolve towards a useful tool in diagnosis and monitoring of the disease. For cancer diagnosis, especially of the reproductive system, it is important to consider whether the patient has already entered a period of menopause.

\section{Therapeutic target - telomerase}

A widespread expression of telomerase in cancer cells, and its lower level in the majority of somatic cells provide a solid basis for the application of specific targeted therapy directed against cancer. Such therapies are focused on inhibiting telomerase activity, forcing cancer cells to stop divisions (by a critical reduction in the telomere length) and redirect them to apoptotic cell death [46]. Control of telomerase is possible at several levels, including the expression of genes encoding telomerase subunits, posttranslational modifications and the phosphorylation of proteins [47]. A lot of methods are focused on the impact on TERT or TR subunits. Chemically synthesized small molecule inhibitors of human telomerase, such as BIBR1532, exhibit a non-competitive inhibitory effect on the telomerase active site of TERT. In preclinical studies on breast cancer (MDA-MB-231) and lung ( $\mathrm{HTI}-\mathrm{H} 430)$ cell lines, a significant decrease in telomere length and inhibition of cell proliferation was observed [48]. Other studies showed that an antisense oligonucleotide - GRN163L, blocks the expression of the TR subunit of telomerase [49]. Since positive results of the preclinical studies were obtained, GRN163L has been introduced into clinical trials (imetelstat), to treat both solid and hematological tumors including breast, lung, liver, prostate and other [47, 49]. Moreover, gene therapy utilizes also siRNA, ribozymes, suicide genes and oncolytic virus genes [43]. Due to the fact that telomerase peptides are tumor specific antigens, great expectations are associated with the use of immunotherapy. The most promising vaccines include GV-1001, GRNVAC1 and Vx-001, targeted to redirect the immune system against tumor cells with telomerase expression [50]. BRACO-19 is a G-quadruplex stabilizing substance and has the ability to induce senescence and apoptosis, with high efficacy against cancer with shorter telomeres [51] (Fig. 1). Furthermore, some researchers indicate a promising aspect of the combination of conventional anticancer therapy with telomerase inhibitors. The enhanced anticancer effect of such therapy was observed especially when G-quadruplex inhibitors were applied in combination with DNA-damaging agents, i.e. doxorubicin, paclitaxel, etoposide [52].

We are focused on identification of telomerase-inhibiting agents but substances that activate telomerase may constitute another important subject of interest. TA-65 - a telomerase activator isolated from plant Astragalus and Ginkgo biloba extract, may become a crucial compound in degenerative diseases treatment and anti-aging therapy [53].

Despite the strengths of the potential use of telomerase inhibitors, we should not forget about the risk 


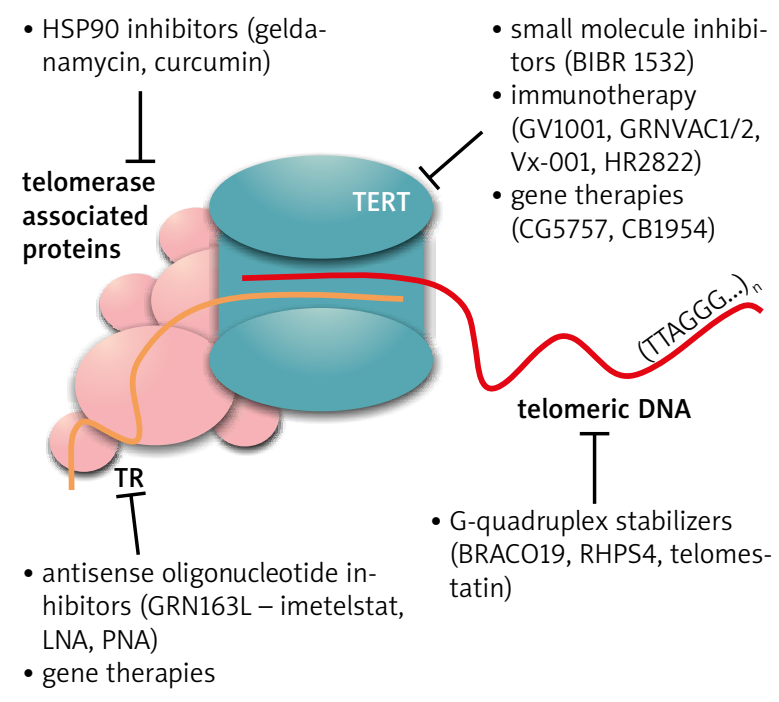

$T R$ - telomerase RNA, TERT - telomerase reverse transcriptase catalytic subunit, HSP9O - heat shock protein 90

Fig. 1. Strategies of targeting telomerase [46-52]

associated with inhibition of the enzyme in healthy cells. A high, constitutive expression of telomerase in germ cells, stem cells and other proliferating cells of the body may be perceived as a real obstacle in the clinical use of telomerase inhibitors. Thus, specific (cell-, tissue-, organ-) telomerase targeting is still a challenging part of cancer research. It is suggested that there is a "therapeutic window" for safe usage of telomerase inhibitors since down-regulation of telomerase activity and telomere shortening in cancer cells occur much earlier than in normal cells, due to shorter telomeres in tumor cells $[53,46]$. Another problem in telomerasetargeting based therapy could be activation of ALT in cancer cells and modulation of the signal transduction pathways leading to apoptosis in response to genomic instability. However, these changes might induce tumor cell resistance, or even promote tumor growth, which must be taken into account when planning novel therapies [54].

\section{Summary and conclusions}

Targeting telomerase has been one of the most promising forms of cancer therapy to date, however new substances are still identified. Their modes of action are based on the presence of telomeres and activity of telomerase. In the age of personalized medicine it is extremely important to adapt therapy to the patient, with a particular reference to the genetic profile of cancer, predisposition of a patient and current physiological condition of the body. Women during and after menopause are a special group of patients. Hormonal changes and their effect on telomerase activity should be taken into consideration when the choice of ap- propriate oncological treatment is made. Furthermore, changes in telomerase activity that are specific to postmenopausal women, give a potential opportunity of using this factor in early diagnosis of cancer. Numerous researchers still search for new, more specific tumor markers. However, more intensive research is needed in the field of telomerase expression/activity measurement that might become a potential marker of malignancy, reflecting diversity of cancer types, development stage and hormonal profile.

The present review was supported by 2011/03/B/ NZ7/00512 research grant.

\section{References}

1. Hiyama K, Hiyama E. Telomerase as tumor marker. Cancer Lett 2003; 194: 221-33.

2. Shay JW, Reddel RR, Wright WE. Cancer. Cancer and telomeres - an ALTernative to telomerase. Science 2012; 336: 1388-90.

3. Mocellin S, Pooley KA, Nitti D. Telomerase and the search for the end of cancer. Trends Mol Med 2013; 19: 125-33.

4. Palm W, de Lange T. How shelterin protects mammalian telomeres. Annu Rev Genet 2008; 42: 301-34.

5. Lu W, Zhang Y, Liu D, et al. Telomeres-structure, function, and regulation. Exp Cell Res 2013; 319: 133-41.

6. Kong $C M$, Lee XW, Wang X. Telomere shortening in human diseases. FEBS J 2013; 280: 3180-93.

7. Rubtsova MP, Vasilkova DP, Malyavko AN, et al. Telomerase and the search for the end of cancer. Acta Naturae 2012; 4: 44-61.

8. Blasco MA. Telomeres and human disease: ageing, cancer and beyond. Nat Rev Genet 2005; 6: 611-22.

9. Weinrich SL, Pruzan R, Ma L, et al. Reconstitution of human telomerase with the template RNA component hTR and the catalytic protein subunit hTRT. Nat Genet 1997; 17: 498-502.

10. Conomos D, Pickett HA, Reddel RR. Alternative lengthening of telomeres: remodeling the telomere architecture. Front Oncol 2013; 3: 27.

11. Collins K, Mitchell JR. Telomerase in the human organism. Oncogene 2002; 21: 564-79.

12. Benko AL, Olsen NJ, Kovacs WJ. Estrogen and telomerase in human peripheral blood mononuclear cells. Molecular and cellular endocrinology 2012; 364: 83-8.

13. Prescott J, Kraft P, Chasman DI, et al. Genome-wide association study of relative telomere length. PLoS One 2011; 6: e19635.

14. Zhou Ch, Steplowski TA, Dickens HK. Estrogen induction of telomerase activity through regulation of the mitogen-activated protein kinase (MAPK) dependent pathway in human endometrial cancer cells. PLoS One 2013; 8: e55730.

15. Cramer DW. The epidemiology of endometrial and ovarian cancer. Hematol Oncol Clin North Am 2012; 26: 1-12.

16. Liang J, Shang Y. Estrogen and cancer. Annu Rev Physiol 2013; 75: 225-40.

17. http://www.cancer.net/coping/emotional-and-physical-matters/sexualand-reproductive-health/menopause-and-cancer-risk-and-treatment.

18. Maraei AA, Hatta AZ, Shiran MS, Tan GC. Human telomerase reverse transcriptase expression in ovarian tumors. Indian J Pathol Microbiol 2012; 55: 187-91.

19. Chen $\mathrm{CH}$, Chen RJ. Prevalence of telomerase activity in human cancer. Journal of the Formosan Medical Association 2011; 110: 275-89.

20. Kumaki F, Kawai T, Hiroi S, et al. Telomerase activity and expression of human telomerase RNA component and human telomerase reverse transcriptase in lung carcinomas. Hum Pathol 2001; 32: 188-95.

21. Yashima K, Milchgrub S, Gollahon LS, et al. Telomerase enzyme activity and RNA expression during the multistage pathogenesis of breast carcinoma. Clin Cancer Res 1998; 4: 229-34.

22. Terry KL, Tworoger SS, Vitonis AF, et al. Telomere length and genetic variation in telomere maintenance genes in relation to ovarian cancer risk. Cancer Epidemiol Biomarkers Prev 2012; 21: 504-12. 
23. Shay JW, Bacchetti S. A survey of telomerase activity in human cancer. Eur J Cancer 1997; 33: 787-91.

24. Wojtyla A, Gladych M, Rubis B. Human telomerase activity regulation. Mol Biol Rep 2011; 38: 3339-49.

25. Lebeau J, Fouchet P, Ory K, Chevillard S. Down-regulation of telomerase activity after progesterone treatment of human breast cancer cells: essential role of the cell cycle status. Anticancer Res 2002; 22: 2161-6.

26. Sanders JL, Newman AB. Telomere Length in Epidemiology: A Biomarker of Aging, Age-Related Disease, Both, or Neither? Epidemiol Rev 2013; 35: 112-31.

27. Boggess JF, Zhou C, Bae-Jump VL, Gehrig PA, et al. Estrogen-receptor-dependent regulation of telomerase activity in human endometrial cancer cell lines. Gynecol Oncol 2006; 103: 417-24.

28. Lee DC, Im JA, Kim JH, et al. Effect of long-term hormone therapy on telomere length in postmenopausal women. Yonsei Med J 2005; 46: 471-9.

29. Lin J, Kroenke CH, Epel E, et al. Greater endogenous estrogen exposure is associated with longer telomeres in postmenopausal women at risk for cognitive decline. Brain Res 2011; 1379: 224-31.

30. Santos LG, da Silva BB. The effect of raloxifene on telomerase expression in breast carcinoma samples from postmenopausal women. Eur J Obstet Gynecol Reprod Biol 2011; 159: 165-7.

31. Wlazlak E, Bitner A, Surkont G, et al. Ocena ekspresji telomerazy w błonie śluzowej jamy macicy podczas cyklu miesiączkowego. Prz Menopauz 2007; 11: 102-5.

32. Menon MM, Simha MR. Telomerase and telomere length in normal and malignant human endometrium as prognostic markers. Indian J Pathol Microbiol 2003; 46: 394-8.

33. Lehner R, Enomoto T, McGregor JA, et al. Quantitative analysis of telomerase hTERT mRNA and telomerase activity in endometrioid adenocarcinoma and in normal endometrium. Gynecol Oncol 2002; 84: 120-5.

34. Yokoyama Y, Takahashi Y, Shinohara A, et al. Telomerase activity in the female reproductive tract and neoplasms. Gynecol Oncol 1998; 68: 145-9.

35. Kinugawa C, Murakami T, Okamura K, Yajima A. Telomerase activity in normal ovaries and premature ovarian failure. Tohoku J Exp Med 2000; 190: 231-8.

36. Liu JP, Li H. Telomerase in the ovary. Reproduction 2010; 140: 215-22.

37. Fajkus J. Detection of telomerase activity by the TRAP assay and its variants and alternatives. Clin Chim Acta 2006; 371: 25-31.

38. Saldanha SN, Andrews LG, Tollefsbol TO. Analysis of telomerase activity and detection of its catalytic subunit, hTERT. Analytical Biochemistry 2003; 315: 1-21.

39. Heaphy CM, Meeker AK. The potential utility of telomere-related mark ers for cancer diagnosis. J Cell Mol Med 2011; 15: 1227-38.
40. Barczak W, Rubis B. Długość telomerów jako marker prognostyczny w raku piersi i raku płuca. Nowotwory 2012; 62: 283-91.

41. Wentzensen IM, Mirabello L, Pfeiffer RM, Savage SA. The association of telomere length and cancer: a meta-analysis. Cancer Epidemiol Biomarkers Prev 2011; 20: 1238-50.

42. Wang SJ, Sakamoto T, Yasuda S, et al. The relationship between telomere length and telomerase activity in gynecologic cancers. Gynecol Oncol 2002; 84: 81-4.

43. Prescott J, McGrath M, Lee IM, et al. Telomere length and genetic analyses in population-based studies of endometrial cancer risk. Cancer 2010; 116: 4275-82.

44. Weischer M, Nordestgaard BG, Cawthon RM, et al. Short telomere length, cancer survival, and cancer risk in 47102 individuals. J Natl Cancer Inst 2013; 105: 459-68.

45. Vera E, Blasco MA. Beyond average: potential for measurement of short telomeres. Aging 2012; 4: 379-92.

46. Shay JW, Wright WE. Telomerase therapeutics for cancer: challenges and new directions. Nat Rev Drug Discov 2006; 5: 577-84.

47. Holysz H, Lipinska N, Paszel-Jaworska A, Rubis B. Telomerase as a useful target in cancer fighting - the breast cancer case. Tumour Biol 2013; 34: 1371-80.

48. Damm K, Hemmann U, Garin-Chesa P, et al. A highly selective telomerase inhibitor limiting human cancer cell proliferation. EMBO J 2001; 20: 6958-68.

49. Röth A, Harley CB, Baerlocher GM. Imetelstat (GRN163L) - telomerasebased cancer therapy. Recent Results Cancer Res 2010; 184: 221-34.

50. Harley CB. Telomerase and cancer therapeutics. Nat Rev Cancer 2008; 8: $167-79$.

51. Burger AM, Dai F, Schultes CM, et al. The G-quadruplex-interactive molecule BRACO-19 inhibits tumor growth, consistent with telomere targeting and interference with telomerase function. Cancer Res 2005; 65: 1489-96.

52. Tamakawa RA, Fleisig HB, Wong JM. Telomerase inhibition potentiates the effects of genotoxic agents in breast and colorectal cancer cells in a cell cycle-specific manner. Cancer Res 2010; 70: 8684-94.

53. Zvereva MI, Shcherbakova DM, Dontsova OA. Telomerase: structure, functions, and activity regulation. Biochemistry 2010; 75: 1563-83.

54. Gocha AR, Harris J, Groden J. Alternative mechanisms of telomere lengthening: permissive mutations, DNA repair proteins and tumorigenic progression. Mutat Res 2013; 743-4. 